\title{
Stealth Democracy, Elitism, and Citizenship in Finnish Energy Policy
}

\section{Ilkka Ruostetsaari, University of Tampere}

\section{Introduction}

Inspired by the international financial and euro zone crises, and by the influx of refugees into Europe, the populist political parties have raised the public agenda the claim that there is a widening gap between the elite and the people. This claim, however, is not new in the field of energy policy, which has been characterized as a policy sector where citizens' involvement is more limited than in most other policy sectors. An American study showed that organizational barriers to more extensive interest representation were higher in the energy sector than in other policy domains [1]. Some firms, especially state-owned and, more generally, those operating in the energy supply, have had privileged access to decision-making arenas, which have remained mostly closed off to average citizens [2].

Similar findings have also been reported in Finland. Despite the new rules of the game - from monopolies and extensive regulation via competition and deregulation to re-regulation - and the Europeanization of the Finnish energy sector, the composition of the energy elite has been fairly stable from the end of 1980 s until the end of the first decade of the 2000s. The energy elite has been dominated by energy producers. Civic associations and consumer-citizens have had difficulties in gaining access to the energy policy decision-making arenas [3].

The purpose of the present study is to address whether the attitudinal distance between the Finnish energy elite (decision-makers and experts) and the citizenry has changed regarding the energy policy between 2007 and 2016, and whether their attitudinal differences were more concerned with the substance of energy policy than with the process of policy-making. The rationale for studying the views of the elites and the citizenry stems from the normative ideals of classical democracy; citizens must be able to influence political decision-making and they 
also actively use this right. This requires responsiveness of the elites towards citizens; the gap between them cannot be wide and above all, it should not grow. The starting point of our study, the year 2007, represents a period of rapid and stable economic growth, while the year 2016 represents the immediate time after a prolonged recession that resulted from both international economic crises and domestic political decisions. A major political scandal also became public in 2008. Thus, the legitimacy of the political rule was called into question.

According to Hibbing and Theiss-Morse (2005, pp. 25, 36, 40), there has been little research on how the citizenry want their democratic process to work. Since the birth of democracy in Athens 2,500 years ago, philosophers have been voicing their opinions on the proper working of government. Since then this has been a major research topic in political philosophy (e.g. Swift 2014) [4] and moral philosophy (e.g. Rachels 2007) [5]. Political scientists have studied citizens' support for specific policies, political parties, governmental institutions, and for democracy in general, but citizens have not often been asked in detail about their attitudes on how they want their government to work [6]. However, in Finland some political scientists have analyzed empirically citizens' attitudes on the working of democratic processes $[7,8]$. Americans, for example, were found to be attuned to the way government works more than to what it produces (i.e., they pay attention to the processes more than the policies). This finding was interpreted to support "stealth democracy", a form of democracy in which people do not want to make political decisions themselves but leave the decision-making in the hands of selfless politicians and various experts [6].

The topic of our study, energy policy, will be defined in this study as the political steering conducted by political decision-makers and public authorities focusing on energy management. Energy policy covers research, planning, decision-making, implementation, and evaluation pertaining to the goals and measures of political decision-makers and public authorities, which focuses on the production, purchase, storage, transfer and delivery of energy, and on energy 
consumption. However, energy policy is not determined exclusively by decisions and measures made by politicians and civil servants, and implementation of energy policy depends heavily on the business sector. Firms and interest groups seek to influence energy policy to promote their own interests and shape its content de facto [9].

Finnish policy-making has special characteristics by international standards. According to Rask (2008, p. 199) and Rucht (1997, p. 283), the Finnish governmental policies for science, technology, and energy (e.g. nuclear power, information technology, and biotechnology) have rested on exceptionally high trust in technology and technological development among the citizenry $[10,11]$. Moreover, with respect to citizens' trust in various societal institutions, the universities, science and research in general were outweighed only by the police and the judiciary [12]. This attitudinal climate has been reflected in decision-making. While construction of new nuclear power plants has been prohibited in many countries, the Finnish Parliament licensed the construction of two nuclear power plants in 2010. Moreover, Finland is among the first countries in which the process for the final disposal of spent nuclear fuel in the bedrock has been authorized both at the national (Parliament in 2001) and local (municipal council in 2000) levels [13]. Permission for construction of the facility was granted in 2015. This study proceeds as follows. First, social changes, mainly deep economic fluctuations and a political scandal, which likely affected the citizens' attitudes from 2007 to 2016, are outlined. Second, the theoretical starting points concerning stealth democracy and the politics of expertise are defined based on previous studies. Third, a model of elite structures for evaluating empirical findings is outlined, and the research methods, datasets, and hypotheses are imposed. Fourth, the analysis is composed of four sections; the two first sections focus on the substance of energy policy, and the attitudes of the energy elite and the citizenry are addressed with respect to their normative views on the Finnish energy policy and the utilization of various energy sources in energy production; the third section focuses on the views of the energy elite and the 
general population on the process of energy policy-making; and the fourth section outlines the support for stealth democracy among the citizenry with different socio-economic backgrounds. Finally, the research questions are answered, and the findings discussed in light of the theoretical starting points.

\section{Changing political involvement in Finland from 2007 to 2016}

After the early 1990s, the societal operating environment of the Finnish elites and the general population was dominated by deep economic fluctuations. The Finnish economy collapsed more drastically in the early 1990s than any other developed market economy after the Second World War [14] and the country plunged into the deepest recession in its history. Social services were cut, and the welfare state began to disintegrate as a result of the cuts in government expenditures. This "great recession" in 1991-1993 was followed by rapid economic growth based mainly on governmental investments in research and development and the expansion of the electronics industry, especially Nokia Ltd. However, Finland's economic boom was halted in 2008 by the international financial crisis and the euro zone crisis. Due to that the Finnish economy is heavily dependent on exports, the GNP decreased by $8 \%$ in 2009 compared with 2008. Although this recession was only about half as severe as the recession of the 1990s, the GNP still decreased in Finland more than in other euro area countries and in those EU member states that had joined the Union before 2004 [15]. The recession originating from 2008 lasted longer than the recession of the early 1990s; the GNP is still approximately 5\% lower than before the crises, and a slight economic growth (0.5\%) started as late as 2015.

In addition to the decreased governmental output as a result of the recession, the elites' legitimacy was challenged by political scandals. In particular, the political elite was disturbed by the election campaign funding scandal of 2008, which was the most serious political scandal 
in Finland to date as measured by the publicity surrounding the events [16]. This scandal together with the international financial crisis, the euro zone crisis, and the Greek and Portuguese bail-outs, which dominated the public debate from 2008 to 2011, undermined the legitimacy of the major political parties and affected the results of the 2011 general election; electoral support of the populist Finns Party increased from 4.1\% in 2007 to $19.1 \%$ in 2011. In the next general election in 2015, the support for the Finns party decreased somewhat $(17.7 \%)$ but the party rose to the inner core of power, i.e., the government. The new government that was formed after the general election of 2015 started to increase employers' benefits and to cut citizens' welfare services to boost economic growth.

A substantial body of scholarly literature indicates that many post-industrial societies have experienced a withdrawal from conventional political activism. This transformation also applies to Finland, with some important exceptions. The voter turnout in Finland $(67.9 \%$ in general the election of 2007; 70.5\% in 2011; and 70.1\% in 2015) was within the lowest third of all Western democracies and has decreased more sharply than in many other countries, especially within Scandinavia [17]. However, Finns' trust in the political and legal systems and in other people was the highest among the 28 EU member states in 2013. [18]. According to the 2008 European Social Survey, Finns participated in civic associations more than people in any of the other 24 countries in the study. However, Finnish people's subjective civil efficacy (the sense that one can understand political processes and participate in them meaningfully) has been much lower, on average, than in Europe. In 2008, it was the third-lowest among 23 European countries [19]. Similarly, Rapeli [20] showed that Finns' knowledge base is not at such a level, which would enable well-argued and thorough discussion on political issues.

Finns also have low civic efficacy concerning energy policy-making. Clearly more than half of the citizens were dissatisfied with their potential to influence energy policy; the proportion of the citizenry who agreed (fully or somewhat) with the statement that "citizens' opinions have 
not been heard sufficiently enough in energy policy decisions" was 71\% (mean) in 1983-1993, $67 \%$ in $1994-2000$, and $64 \%$ in $2001-2007$ [21].

Stolle and Micheletti (2006, pp. 266, 39) have argued that political consumerism may substitute for conventional forms of participation that are increasingly perceived as less efficient and less suitable for the global nature of political problems. Political consumerism can be defined as "actions taken by those who make choices among producers, products and services with the aim of changing objectionable institutional or market practices." [22]. In Finland, as in the Nordic countries in general, the endorsement of political consumerism has been relatively high since 2007. With respect to influencing the energy policy-making Finns' have more trust in their consumption choices than voting in general elections [23].

All in all, since 2007 the Finnish citizenry has been characterized, in international comparison, by low levels of voter turnout, civic efficacy, and political knowledge but high support for political consumerism. All of these factors reflect citizens' low trust in their possibilities to influence policy-making trough representative democracy. Moreover, the economic downturn, a major political scandal, and the influx of refugees have undermined governments' output in the face of the citizenry. However, simultaneously the citizenry has been profiled by high trust in the regime and technology. Because of this special attitudinal combination we may anticipate that citizens are increasingly willing to give political decision-making in the hands of experts rather than elected officials, as the theory of stealth democracy suggests. However, it is unnecessary and even impossible on the basis of available data to specify the effect of these individual factors on the endorsement of stealth democracy. This ambivalent attitudinal climate together with the tradition of energy policy as a relatively closed policy sector for citizen involvement make Finland a particularly fruitful object for studying the relationship between the energy elite and the citizenry and for testing the theory of stealth democracy. 


\section{Approach of stealth democracy to political involvement}

A common notion among social scientists concerning citizens' strong, even increasing interest in political involvement has been challenged. According to Hibbing and Theiss-Morse (2005, $1-2,143,127)$, rather than wanting a more active, participatory democracy, a large number of people want what they call "stealth democracy". Their claim is that the people do not routinely play an active role in decision-making, or in providing input for or monitoring decision-makers. The goal in stealth democracy is for decisions to be made efficiently, objectively, and without commotion and disagreement. Stealth aircraft such as B-2 bombers are difficult to see with standard radar techniques, but everyone knows they exist. Similarly, the citizens want democratic procedures to exist but not to be visible on a routine basis. They want to be able to make democracy visible and accountable on those rare occasions that they are motivated to be involved. Just like stealth bombers can be made to show up on radar when desired, the citizenry want to know that their government will become visible, accountable, and representative should they decide such traits are warranted. However, until that time, most people prefer not to be involved and therefore desire unobtrusive accountability. Thanks to representatives, people do not need to constantly pay attention to many issues about which they do not care. Because individuals are often too uninformed, unmotivated, or narrow to exert appropriate political influence, politicians should make the decisions for them [6].

We cannot fully understand citizens' attitudes toward government without taking into account how they think government ought to work and how they think government works in practice. As far as the citizens' attitudes toward government are concerned, they are more affected by the process of government than by the policies government enacts. Dissatisfaction usually stems from perceptions of how government does its business, not what the government does. In fact, 
the policy matters, but process, rather than policy, is often a better predictor of citizens' attitudes and behaviors with respect to government [6].

The fact that citizens have preferences for policy and process has also been shown in European studies. In the absence of clearly formulated interests and related identities that representatives could work to promote, elected officials have become more and more detached from their constituency. Voting has come to resemble a Schumpeterian [24] picture of democratic elitism where the main concern is to elect people into positions of power, leaving actual issues of substance and policy directions largely indeterminable. This is a particular concern in the Finnish proportional electoral system where citizens can never know at the ballot box exactly how their votes will be used; which political parties will form the government coalition, and what objectives they will adopt in the government program [25].

Hibbing and Theiss-Morse (2005, pp. 7, 122, 85-6, 139-143) argue that people want to distance themselves from government not because of a system defect but because many people are simply averse to political conflict and many others believe political conflict is unnecessary and an indication that something is wrong with governmental procedures. Elites are not what the citizens fear; rather, it is self-serving elites who are feared. The citizenry is surprisingly smitten with the notion of elite experts making choices - provided that those experts have nothing to gain from selecting one option over another. Because the citizenry agrees on societal goals, no conflict need exist, and governing is reduced to the mechanical process of implementing a good plan for attaining these goals. Determining appropriate policy action thus requires no elaborate institutions and powerful elected officials. In short, contrary to conventional wisdom, the citizenry like the concept of objective bureaucrats making their technical decisions. "People want to avoid government by people who act selfishly, not government by experts and elites" [6]. Thus, stealth democracy represents elitist conception of democracy. 
However, the stealth democracy claim that the experts representing, for example, business and public administration are legitimate policy-makers equal to the elected officials, has long been challenged for by several scholars. According to Frank Fischer (1990, pp. 14-21, 40, 148), fundamental to the critique of technocratic expertise is the argument that experts have overrelied on and misused scientific and technical knowledge. Thus, technocracy is a deepseated challenge to democracy and its political form of decision-making [26].

Western science and technology policy has generally been seen as a policy sector that is dominated by experts and public administration, where political decision-makers have neither played, nor had an aspiration to play a role [27, 28]. This is also the case in Finland; governmental policy-making in the field of science and technology has been dominated by experts, perhaps more so than any other policy sector. Despite its vital position in societal development, however, this has played only a marginal role in the agenda of political parties and Parliament. Although most political parties had comprehensive party programs dealing with science policy as early as the 1960s and 1970s, these programs have since been absent. In fact, the link between science and technology policy and civil society has remained more fragile than the link with political decision-makers [29]. However, Finns have trusted most in the technology among various actors or devices in solving the environmental problems caused by energy production and consumption [9].

\section{Model of elite structures, research questions and hypotheses}

The existence of elites is an unavoidable fact in all past and current societies, both in democratic and un-democratic ones [30]. Elites and democracy are not necessarily mutually exclusive but the compatibility of elites with democratic principles depends on elites' characteristics or types. A typology of elite structures can be outlined based on two variables; degree of the elites' 
openness and degree of their coherence. The elite structure can be described as coherent (or exclusive) when the elites come from a more privileged socio-economic background than the citizenry; they are recruited from society's highest strata; they have very close mutual contacts, and they share similar attitudes. There is a wide gulf between the attitudes of elites and the citizenry. At the other end of the typology, a fragmented elite structure is characterized by a broad socio-economic recruitment base, limited interplay between elites, and a wide gulf between various elites in terms of attitudes. Elites might share certain societal rules of the game in common, for instance a consensus about the democratic process, but they differ in their views about many societal objectives. On the other hand, there are close links between the citizenry and elites, and they share similar attitudes. In a coherent elite structure consensus among the various elite groups is so strong that we can talk about the existence of a single power elite [31]. In a fragmented elite structure, by contrast, the consensus among elites is so weak that it is not justified to talk about a single power elite. As regards the functioning of democracy, a coherent elite structure is inadequate, whereas a fragmented elite structure best meets the criteria for classical democracy [32]. This theoretical model will be applied in this study to analyze the attitudinal differences between the energy elite and the citizenry as well as in interpreting the empirical findings.

The research question in the present study was to address whether the attitudinal distance between the Finnish energy elite (decision-makers and experts) and the citizenry has changed with respect to the energy policy between 2007 and 2016, and also whether their attitudinal difference have been more concerned with the substance of energy policy than the process of policy-making. Based on the theory of stealth democracy, we empirically tested four hypotheses concerning the elite's and citizens' views on the substance and process of energy policy; we focussed on the normative views dealing with the statements concerning energy policy, the use of various energy sources, and the principles dealing with the process of energy policy-making. 
We hypothesized, first, that the citizenry endorses stealth democracy more than the energy elite. Because citizens' civic efficacy was rather low, they felt that their opinions were not sufficiently heard in energy policy-making and their trust in elected officials was relatively low as a result of decreased governmental output caused by the international financial crisis (2008), the euro zone crisis (2009), the election funding scandal (2008), and the refugees influx into Finland (32,000 in 2015). For example, Finns' trust in the government decreased in 2007-2012, on average, more than in other OECD countries [33]. Citizens likely trusted more in experts representing business and public administration, who they saw as more objective and independent than the elected officials. However, the elite, that is decision-makers and experts, were more knowledgeable, owing to their high levels of education and occupation, than the general population with respect to who should have the final say in the democratic decisionmaking process, according to the Constitution. Moreover, the elite members were themselves decision-makers, or at least influential experts in the field of energy policy. It is evident that the effects of above-mentioned societal changes on the elite were lesser than on the general population. Thus, we hypothesized, second, that the support for stealth democracy increased among the citizenry but remained unchangeable within the energy elite from 2007 to 2016.

Our third hypothesis was that the attitudinal distance between the energy elite and the citizenry is lesser related to policy than to process. In other words, the elite's and the citizenry's perceptions of the substance of energy policy were closer to each other than to the ways and by whom the decisions are made. The theory of stealth democracy suggests that people are affected more by the process of government than by the policies government enacts, and their dissatisfaction usually stems from perceptions of how government operates, not what the government does [6].

We hypothesized, fourth, that socio-economically underprivileged people endorse stealth democracy more than the privileged. This hypothesis was based on the findings of the Finnish 
electoral study that the privileged citizens vote more actively in general elections and have a higher civic efficacy than the less privileged. The variables under study were sex, age, education, field of education, occupational position, political party identification, and the type of home ownership all of which have explained citizens' electoral behaviour [34].

\section{Datasets of the study}

Methodologically, this study was based on postal surveys (and an Internet survey in 2016) conducted among a random sample representing Finns aged 18-75 years. The field work, including one reminder round, was carried out from May to October, 2007 and August to October, 2016. The rate of response was rather low (30.0\% in 2007 and $33.6 \%$ in 2016), but the large sample size $(\mathrm{N}=4000)$ ensured that the data sufficiently represented the general Finnish population.

However, the data deviates in minor respects from the whole population. People living in small municipalities $(4,000-8,000$ inhabitants) were somewhat overrepresented, while those living in large municipalities (more than 80,000 inhabitants) were underrepresented. However, the respondents represented the various regions of the country with an even distribution. Individuals living in detached houses were clearly overrepresented but those living in apartment houses or terraced houses were underrepresented. Similarly, people living in their own flats were overrepresented, while those living in rented flats are underrepresented. Compared to the population at large, the highly educated (individuals with at least a Master's degree or equivalent) were overrepresented. For education fields, people educated in the engineering and service branch were somewhat underrepresented. With regard to occupational groups, lower functionaries were underrepresented, while blue-collar workers and pensioners were somewhat overrepresented $[35,36]$. It is possible that the respondents were somewhat more interested in 
energy issues than the general population. In 2007, 26\% had changed their electricity supplier, while in 2016 , this number was as high as $52 \%$.

The third elite dataset was collected between December 2008 and March 2009, and the number of respondents in the structured elite interview was 25 (seven firms, six energy organizations, three civic associations, four civil servants, five members of parliament). I conducted all of the elite interviews. The array of the elites interviewed in all three studies was based on the positional approach in which actors representing the most salient institutions in the sector were discovered using an analysis of previous studies and register data. This method was supplemented with the reputational approach; the interviewees were also questioned about other influential actors in the sector (so-called snowball sampling) but the original list of elite actors did not change [37].

The fourth dataset was collected among the energy elite (i.e., decision-makers and experts in the field of energy policy) from August to October 2016; data was collected using structured online survey including two reminder rounds. This was also a survey in which the selection of respondents was based on a positional approach. The number of respondents was 93 out of 361 people $(25.8 \%)$ who were sent the questionnaire. The group of respondents was large, comprising MPs, central government officials, decision-makers and experts functioning in the production of district heating, energy services, electricity trade, national, regional and local electricity production, electricity grids, equipment manufacturing, importation of energy technology, energy intensive firms, building industry, real estate management, environmental and other civic associations, universities, research institutes, and the mass media. The respondents were distributed evenly between these sectors of energy policy.

As regards comparability of four datasets, a limitation concerns the number of elite interviews (24) conducted in 2008/2009. In the context of quantitative approach this number of 
interviewees can be seen as small but within the scope of qualitative study this number is not a major problem. Most importantly, the group of interviewees should comprise all relevant subgroups of the research object [38]. The interviewed persons in our study comprised the most important stakeholders of energy policy as did the postal survey conducted among energy elite members in 2016. Moreover, the number of people belonging to the Finnish energy elite has traditionally been very small [39].

In terms of timing, the elite interviews were carried out a little later than the postal survey was conducted among the citizenry in 2007 . Nevertheless, these datasets can be roughly compared due to that wide-ranging effects of the international financial crisis and euro-zone crisis were not yet materialized in the Finnish national economy prior to the elite interviews were accomplished. Postal surveys among the citizenry were conducted identically in 2007 and 2016. Above all, the energy elite and the citizenry were asked entirely identical, structured questions in both periods under study. Thus, despite these limitations data-collection methods are reliable enough as the same procedures were applied in the same way [40]; these four datasets make it possible the comparison of attitudes within the elites and the citizenry as well as between them. In fact, the number of studies where the elites and citizenry are compared longitudinally is relatively limited, especially in the field of energy policy.

\section{Attitudes on the normative statements concerning the Finnish energy policy}

The energy elite and the citizenry were asked a structured question in 2016, as follows: "What is your opinion on the following statements concerning energy policy?" The response options were "fully agree", “somewhat agree”, "somewhat disagree”, "fully disagree”, and "can’t say”. With respect to the substance of the Finnish energy policy (Table 1), the energy elite stressed more the role of (global) market-based mechanisms in energy policy-making than the general 
population; the greatest difference concerned the statements that "energy markets should be allowed to operate on the market terms", and "there is sufficient competition between the electricity suppliers" both of which the energy elite endorsed more than the citizenry. Conversely, the elite emphasized less the importance of national self-sufficiency in energy sector and the increased public subsidies to speed up the utilization of new technology than the general population

Table 1 about here

Unanimity, i.e., coherence within the energy elite and the citizenry in terms of normative statements can be measured using an index, as follows: (fully agree $\%+$ somewhat agree $\%$ ) (fully disagree $\%+$ somewhat disagree $\%$ ) $/ \mathrm{N}^{1}$. The higher the index, the more unanimous was the elite or the citizenry. The index score for the elite was 30.0, and for the citizenry 30.3. Thus, the energy elite was as unanimous or coherent as the general population. Moreover, the attitudinal distance between the energy elite and the citizenry can be measured by the standard deviation with respect to the statements ${ }^{2}$. The score was 16.0. These indexes of coherence and standard deviation are also used in the following analyzes to compare the elites with the general population.

\section{Utilization of various energy sources for energy production in the future}

The energy elite and the citizenry were presented with a structured question: "In what direction should the utilization of the following energy sources be developed in Finland?"3 The question

\footnotetext{
${ }^{1} \mathrm{~N}$ is the number of statements in Table 1.

2 In Table 1 "difference" between the elite and citizenry/N.

${ }^{3}$ The total energy consumption by energy sources in Finland in 2015 was as follows: wood fuels $25.6 \%$ (20.5\% in 2007), oil $23.9 \%$ (24.6\%), nuclear energy $18.7 \%$ (16.7\%), coal $8.0 \%$ (13.0\%), natural gas $6.1 \%(10.0 \%)$, hydro power
} 
was the same in all surveys conducted in 2007 and 2016, except that in the 2016 survey "the future" was defined by the year 2030. Response options were "increase substantially", "increase a little", "nowadays appropriate”, “curtail a little”, “curtail substantially”, “close down totally”, and "can’t say" (Table 2).

Table 2 about here

In terms of the utilization of various energy sources, the energy elite were much more unanimous than the citizenry in terms of coherence index. The index scores for the elite were 70.5 in 2007 and 62.3 in 2016, and for the citizenry 53.8 and 53.7. ${ }^{4}$ The findings indicate that the unanimity, or coherence, within the elite decreased, while it remained unchanged among the citizenry. The coherence among the elite and the citizenry was noticeably higher in terms of the utilization of various energy sources (Table 2) than with respect to the statements of energy policy (Table 1).

The greatest differences between the elite and the citizenry in 2007 concerned the utilization of nuclear power, wood fuels, and biogas, all of which the elite preferred more than the general population. In 2016, the differences were smaller but they concerned the same energy sources as in 2007. The greatest disagreement between the elite and the population during the entire research period involved the future of nuclear power in energy production. However, dissension about nuclear power decreased, which can be explained by the fact that the additional construction of nuclear power was much debated before Parliament accepted it in 2010, while in 2016 it was less prominent in the mass media agenda.

$4.6 \%(3.5 \%)$, net import of electricity $4.5 \%(3.1 \%)$, peat $4.1 \%(6.9 \%)$, wind power $0.6 \%(\sim 0 \%)$, and other $3.8 \%(1.7 \%)$ (Statistics Finland 2007; 2016a).

${ }^{4}$ Unanimity within the elite and the citizenry can be measured by an index: (increase substantially $\%+$ increase a little $\%$ ) - (curtail substantially $\%+$ curtail a little $\%+$ close down totally)/N. 
The attitudinal distance between the elite and the citizenry can be measured again by standard deviation in terms of utilization of various energy sources. Thus, the standard deviation between the elite and the citizenry was 15.2 in 2007 and 8.7 in 2016, respectively. This means that the attitudinal distance between the energy elite and the citizenry decreased. The attitudinal distance between the elite and the general population was clearly lesser in 2016 in terms of the utilization of various energy sources than with respect to the statements many of which addressed the ways energy policy is directed (Table 1). This suggests that the differences between the energy elite and the general population may especially concern the process of policy-making.

\section{The process of energy policy-making}

The respondents were asked a structured question, as follows: "How great is the importance that you attach to following principles in energy policy-making?" The response options were "very important", "fairly important", "not really important", "not important at all", and "can’t say". (Table 3).

Table 3 about here

In 2007, the greatest difference between the energy elite and the citizenry concerned the statement according to which experts should be in charge of decision making. While $91 \%$ of the general population perceived this statement as important, only $38 \%$ of the elite were of the same opinion. The other major differences concerned the principles according to which those politically responsible to the constituency should be in charge of decision-making (the elite stressed this more), and decisions should be made by consensus based on negotiations (the citizenry stressed this more). In 2016, the greatest difference between the elite and the general population dealt with the same statement as in 2007 , i.e., the experts should be in charge of 
decision-making, which the citizenry underscored more than the elite. Another major difference concerned the statements according to which environmental organizations should play a central role in decision-making (the citizenry stressed this more).

The firms' role in decision-making was stressed both in 2007 and 2016, slightly more by the elite but the difference between the elite and the citizenry was marginal. The elite accentuated more the role of business organizations in decision-making than the general population in 2007, while in 2016 there was no difference. Moreover, the elite perceived the participation of firms in decision-making as being slightly more important than the citizenry since 2007.

Our finding that citizens were willing to see political power more in the hands of non-elected experts than businessmen was in agreement with Bengtsson and Mattila's (2009, p. 1040) survey conducted among Finns in 2007 (not focused on energy policy). They found that approximately $30 \%$ were in favor of giving power to a more pronounced experts, while less than $20 \%$ wished to give more power to business leaders. These shares are lower than in our survey that focused on energy policy. Results from the world values survey of 1995, however, provided a different result, which indicated that political or economic factors might strongly influence the answers. Finland showed the strongest support among Western democracies for an extended use of expert rule in political matters. As much as $61 \%$ of the Finnish respondents gave a positive response to this question in 1995, compared with $33 \%$ in Norway, $34 \%$ in the US and 38\% in Sweden 2009 [7].

Our datasets suggest that the citizens prioritized the involvement of the experts and representatives of firms more than elected officials in energy policy-making. Moreover, the citizenry stressed the importance of consensus and negotiations, which avoids conflicts in energy policy-making more than the elite. However, the elite accentuated the role of elected 
officials in decision-making more than the general population. These findings are consistent with our hypothesis that the citizenry endorses stealth democracy more than the elite.

In terms of the process of energy policy-making, the energy elite were more unanimous (coherent) than the citizenry; index scores for the elite were 66.4 in 2007 and 55.4 in 2016, and for the citizenry, they were 53.4 and 52.6 , respectively. Thus, the attitudinal unanimity has decreased within the elite but also to a lesser extent among the citizenry from 2007 to 2016. The attitudinal distance between the elite and the citizenry in terms of the process can again be measured by the standard deviation. Because the standard deviation was 17.4 in 2007 and 10.1 in 2016, we may conclude that the attitudinal distance between the elite and the general population has decreased from 2007 to 2016 . As a result of that the standard deviation between the elite and the citizenry with respect to use of various energy sources was 15.2 in 2007 and 8.7 in 2016 (Table 2), our hypothesis in that the attitudinal distance between the elite and the citizenry is lesser in relation to policy than to process was verified. However, in terms of statements (Table 1) the standard deviation was 16.0 in 2016, i.e., even higher than with respect to a process in the same year that did not support the hypothesis.

To test our hypothesis in that the support on stealth democracy has increased among the citizenry but remained unchanged within the elite from 2007 to 2016, we constructed a sum variable from five of the statements mentioned in Table 3. The five statements all depict the claim of stealth democracy, as follows: "experts should be in charge of the drafting of decisions", "experts should be in charge of decision-making", "representatives of firms should take part in decision-making", "business organizations should play a central role in the decisionmaking", and "decisions should be made by consensus as a result of negotiations". The mean support (very or somewhat important) for the sum variable among the elite was $61.0 \%$ in 2007 and $63.0 \%$ in 2016 , while among the citizenry, it was $71.0 \%$ and $72.2 \%$, respectively. Thus, 
our hypothesis was not verified because the endorsement increased slightly among both the elite and the citizenry from 2007 to 2016.

Our findings exposed a striking decreasing appreciation for democracy within the energy elite. In $2007,92 \%$ of the elite agreed with the statement according to which those politically responsible to the constituency should be in charge of decision-making, but this number was no more than $68 \%$ in 2016 . However, of the elite $38 \%$ in 2007 and $68 \%$ in 2016 agreed with the statement that experts should be in charge of decision-making. Moreover, the support for the idea that citizens should be able to influence decisions decreased from $76 \%$ to $61 \%$ in 2007 and 2016, respectively.

\section{Effects of socio-demographic background on the support of stealth democracy}

\subsection{Civic efficacy}

We have shown above that the citizens prioritized the involvement of experts and businessmen more than that of elected officials in energy policy-making. But how the ordinary people experience their own role in energy policy-making?

To analyze the endorsement of stealth democracy among various citizens groups, we used the sum variable constructed in the previous chapter. The response options of "very important" or "somewhat important" were coded as an endorsement of stealth democracy, while the options of "not really important", "not important at all", and "can't say" were coded as nonendorsement of stealth democracy.

Table 3 showed that three-fourths of people perceived their involvement as important in energy policy-making. However, energy issues have not played an important role in the electoral arena; the number of citizens who admitted that energy issues had affected their voting decision in the 
last general election was only $25 \%$ in 2007 and $23 \%$ in 2016. The support for stealth democracy was higher among people whose voting decision was affected by energy issues compared with those whose voting decision was not affected. The dependence was statistically significant both in $2007(\mathrm{p}<.05)$ and $2016(\mathrm{p}<.001)$.

In $2007,44 \%$ of citizens agreed (fully or somewhat) with the statement "I am well acquainted with energy issues", while the proportion (57\%) was clearly higher in 2016 . The support for stealth democracy was higher among citizens who felt that they were knowledgeable in energy issues than among those who were not. The dependence was statistically significant only in 2016 (p<.001). However, Finns' subjective civic efficacy in the field of energy policy was low; only $25 \%$ in 2007 and $24 \%$ in 2016 perceived that they can influence the Finnish energy policy by their own action, while $66 \%$ of the elite were of the same opinion in 2016. People who perceived having possibility to influence supported stealth democracy more than those who did not trust in their possibility to influence. However, the dependence was statistically significant only in $2016(\mathrm{p}<.001)$.

In $2016,52 \%$ of people agreed with the statement that "citizens' opinions have not been heard sufficiently in energy policy decisions" (29\% disagreed), while $40 \%$ of the elite agreed (57\% disagreed). However, the Finns' overall sense of powerlessness has decreased significantly; in 1983-2007, the proportion of those who agreed with this statement was more than $60 \%$ (Energy Attitudes 2007). In 2016, support for stealth democracy was higher among people who agreed with the statement than among those who disagreed with it $(\mathrm{p}<.001)$, while among the energy elite members the relationship was the reverse. These findings suggest that there were differences with respect to endorsement of stealth democracy among people with different socio-economic characteristics which will be addressed next. 


\subsection{Sex and age}

Due to the fact that political consumerism, an alternative form for electoral participation, was found in previous studies to be connected to the citizen agency of women and the young [22], we expected that women support stealth democracy (which also can be seen as an alternative practice for controlling decision-makers through elections) more than men. Because young people generally voted less actively in general elections and trusted less in conventional modes of political participation than older people [32], we anticipated that young people will approve of stealth democracy more than older people.

In contrast to our expectations, women did not support stealth democracy more than men (Table 4). In 2007, the endorsement was the same among men and women (78\%), while in 2016 it was slightly higher among women $(80 \%)$ than men $(77 \%)$. Our expectation concerning the effect of age was also not observed. The endorsement of stealth democracy increased linearly from the youngest age cohort of 18-29-year-olds to the oldest age cohort of 60-75-year-olds in 2007 and 2016.

Table 4

\subsection{Education and occupation}

The high levels of education and occupational position have generally been connected to active electoral participation [34]. Thus, we anticipated that highly educated people and individuals with a high occupational status would support stealth democracy less than other people because more well-off people have more material and knowledge-based resources at their disposal. Due to that the energy sector is very technical in nature, we expected that people with an engineering education would endorse the important role of experts representing business or public 
administration, such as their colleagues, in energy policy-making more than people educated in other areas, for example, in humanities.

Basic education partly explained the adherence to stealth democracy; the share of supporters of stealth democracy was lowest among people with the highest level of basic education, i.e., completed their matriculation examination. However, adherence to stealth democracy was not highest among people with lowest education (primary school) but among individuals with elementary school education.

The endorsement of stealth democracy was not statistically dependent on vocational education. Contrary to our expectations, support was lowest among the least educated citizens, i.e., those who had no occupational education at all in 2007 rather than among the most highly educated citizens. However, it was the second lowest among people with highest education, i.e., those with an academic education. In fact, the adherence to stealth democracy was highest among citizens with the second lowest education, i.e., vocational course. Thus, our finding differed from that of a Finnish survey conducted in 2007 among the general population in which the support on stealth democracy correlated with lower education levels [7].

In 2007, endorsement of stealth democracy was lowest among citizens with education in the natural sciences (67\%), humanities and arts (65\%), business (77\%), and engineering (77\%), and highest among people educated in pedagogics (89\%). In 2016, the adherence to stealth democracy was lowest among citizens educated in social sciences $(65 \%)$ and agriculture and forestry science (75\%), and the highest among people with a business education (84\%). Thus, the effect of the education field was not that what we expected ( $p>.05)$.

Our expectation about a negative connection between a high occupational position and the support for stealth democracy was partially realized. In 2007, the support for stealth democracy was highest among the unemployed, pensioners and entrepreneurs, and lowest among students, 
upper functionaries, and people with a leadership position. In 2016, the endorsement was highest among farmers and lower functionaries but lowest among the unemployed, students, upper functionaries, and people with a leadership position.

\subsection{Type of accommodation and political affiliation}

Individuals who own their residences have had higher likelihood of voting in general elections than those living in rented flats. This may partially be a result of greater stability with respect to residency and thus reflecting social attachment [34]. Hence, we expected that citizens living in rented flats endorses stealth democracy more than those who own their residence. This was the case in 2007 but not in 2016. In 2007, 80\% of citizens who lived in rented flats endorsed stealth democracy, while the proportion was $78 \%$ among people who owned their residences; in 2016, the relationship was the reverse $77 \%$ and $79 \%$, respectively. The dependency was not statistically significant ( $p>.05)$.

The degree of attachment to the political system has varied to some extent between the voters of different political parties. The interest in politics, a sense of civil efficacy, and the level of knowledge on politics have been higher among the voters of the Conservatives and the Left Alliance than among the supporters of other political parties [41]. Thus, we anticipated that the supporters of the Conservatives and the Left Alliance would endorse stealth democracy less than supporters of other parties.

However, our expectations were not realized. In 2007, stealth democracy was supported most by the respondents who identified themselves with the Left Alliance, the Greens, and the Conservatives, while the adherence to stealth democracy was lowest among citizens who did not want to disclose their political party identification, would not vote at all, and couldn't say their party affiliations. In 2016, it was highest among supporters of the Christian Democrats 
and the Swedish People's Party of Finland, and lowest among those who would not vote at all as well as supporters of the Finns' Party and the Greens.

All in all, the dependence between the endorsement of stealth democracy and variables measuring citizens' socio-economic background was statistically significant only in terms of age in 2007 and 2016, and political affiliation in 2016 (Table 4). As our expectations that were derived from the electoral behaviour of various citizens' groups did not materialize, our hypothesis in which socio-economically underprivileged people endorse stealth democracy more than the privileged was not verified.

\section{Results}

The present study addressed whether the attitudinal distance between the Finnish energy elite (decision-makers and experts) and the citizenry has changed with respect to the energy policy between 2007 and 2016, and whether the attitudinal difference was more concerned with the substance of energy policy than the process of policy-making.

With respect to use of various energy sources in energy production in the future, the attitudinal distance between the energy elite and the citizenry decreased from 2007 to 2016 . The attitudinal distance between the elite and the general population in 2016 was clearly lesser regarding use of various energy sources than with respect to the statements about energy policy. Thus, in terms of the substance of energy policy, the attitudinal distance between the energy elite and the citizenry decreased from 2007 to 2016 . Additionally, the attitudinal gap decreased between the elite and general population regarding the process. Our hypothesis in which the attitudinal distance between the energy elite and the citizenry is lesser in relation to substance, i.e., related more to policy than to process, was verified when the relationship to the policy was measured by the views on the utilization of various energy sources. However, with respect to policy 
statements concerning energy policy-making, the attitudinal distance between the elite and the general population was even larger than for the process, which did not support the hypothesis.

Our findings dealing with the process of energy policy-making indicated that the citizens prioritized participation of experts and representatives of firms more than that of elected officials in energy policy-making. Moreover, the citizenry stressed the importance of consensus and negotiations, i.e. avoiding conflicts in energy policy-making. However, the elite stressed the role of elected officials in decision-making more than the general population. These findings are consistent with our hypothesis that the citizenry endorses the stealth democracy more than the elite. In contrast to the hypothesis, however, the role of firms and business organization in decision-making was stressed slightly more by the elite, but the difference between the elite and general population was marginal. We also hypothesized that the support for stealth democracy has increased among the citizenry but remained unchangeable within the elite from 2007 to 2016. This hypothesis was not verified; the endorsement of stealth democracy increased slightly among the elite and citizenry from 2007 to 2016, even more within the elite than among the citizenry.

Our last hypothesis suggested that socio-economically underprivileged people endorse stealth democracy more than privileged people. This hypothesis was based on the findings of the Finnish electoral studies, which indicate that privileged citizens vote more actively in general elections and have higher civic efficacy than less privileged citizens. The variables under study, which we expected to have an effect on the endorsement of stealth democracy, were sex, age, education, field of education, occupational position, political party identification, and type of home ownership. However, our expectations were not realized, and for thus, our hypothesis was not verified. Citizens' attitudes on stealth democracy, therefore, were not clearly related to their levels of conventional political involvement and civic efficacy. 
Because active democratic involvement has been linked in most previous studies to citizens with a well-off socio-economic background, it is striking that in the case of stealth democracy in the field of energy policy, there was neither a positive nor negative connection. However, the same conclusion was made in a survey conducted among the American population in 1998; none of the demographic variables (sex, age, income, race, education) accounted for variations in support for stealth democracy. However, our findings in terms of political affiliation differed from the findings of previous American [6] and Finnish [39] studies that we conducted among the general population; in the field of Finnish energy policy conservative citizens were not more likely to favour stealth democracy than liberals, and by contrast, non-partisans were less supportive of stealth democracy than partisans.

Our starting point was the supposition that government's decreasing economic and political output since 2008 would have increased the attitudinal gap between the energy elite and the general population with respect to energy policy-making. Citizens' trust in political decisionmakers is important due to the fact that important energy policy decisions are dependent on their political acceptability. As the attitudinal distance between the energy elite and the citizenry decreased both in terms of the substance and the process of energy policy from 2007 to 2016, the economic and political fluctuations do not seem to have affected people's views. This is consistent with the finding of previous studies. Scholars have tested whether societal conditions, such as a booming economy, cause people to be satisfied with government. Although surges in support for government sometimes seem to occur during strong economic times, systematic analyses invariably question the role of economic conditions. Policy performance explains little when it comes to public trust in political institutions [42]. However, it has been observed that citizens' perceptions of national economy affect more their voting decisions than changes in macro-economic conditions [43]. In fact, according to the Finns' evaluations, the societal influence of political institutions increased in the context of a recession (in 1991-1993, 2008- 
2011) but decreased during the booming economy (in 1994-2007). However, evaluations regarding economic institutions such as firms showed the opposite results [30]. The attitudinal distance between the energy elite and the citizenry decreased in terms of the distribution of influence in energy policy-making [21].

How these findings can be assessed from the point of view of functioning of democracy. For this purpose we outlined a model of different types of elite structures. The elite structure can be described as coherent (or exclusive) when elites share similar attitudes, and there is a wide gulf between the attitudes of elites and the citizenry. By contrast, a fragmented elite structure is characterized by a wide gulf in attitudes between various elite groups, and the elites share similar attitudes with the general population. As regards functioning of democracy, a coherent elite structure is inadequate, whereas a fragmented elite structure best meets the criteria for classical democracy [32]. As our findings indicated that the attitudinal coherence within the energy elites has decreased and the attitudinal gap between the elites and the citizenry has reduced in terms of the substance and process of energy policy, the elite structure of the Finnish energy policy has moved from a coherent type to the direction of a fragment type from 2007 to 2106. Thus, this transformation can been as positive in terms of functioning of democracy. This kind of elite structure provides good conditions for developing both the substance and the governance of energy policy. The Finnish relatively fragmented energy elite structure -together with citizens' high trust in the political system, low sense of subjective civil efficacy, and relatively low voter turnout - may explain the fact that the Finnish Parliament could authorize the process for the final disposal of spent nuclear fuel in the bedrock in 2001 and license the construction of two nuclear power plants in 2010, while in many countries the use of nuclear power has been challenged or terminated completely. 


\section{Discussion}

Our finding that education did not correlate with the endorsement of stealth democracy is important because a high level of knowledge can be seen as a resource that is needed in societal involvement. Rapeli (2010, p. 158) has observed that the level of education is not a primary factor in Finland, which distinguishes individuals in terms of their knowledge on politics [20]. Delli Carpini and Keeter (1996) have suggested that in so-called pragmatic democracies, most citizens have an average level of knowledge about politics, and there are few individuals who have little knowledge or who are very knowledgeable [44]. Rapeli's study indicated that the U.S. was an example of a pragmatic democracy where citizens' knowledge of politics was fairly equal, even if Finland was even more egalitarian than the U.S. In Finland, the middle stratum was larger, while the proportion of individuals classified as uninformed was lesser than in the U.S. However, in Finland, the proportion of those who are highly knowledgeable about politics was not larger than in the U.S. In short, the level of political knowledge among Finns was relatively high [18].

Finns' interest in politics was relatively high; it was the eighth highest among 24 European countries in 2010 [19], while Hibbing and Theiss-Morse claimed that Americans' interest was rather low [6]. Because the interest in politics correlates strongly with knowledge about politics [20] and Finns' trust in parliament, political parties, and elected official was high (the sixth highest among 24 European states in 2010), we could expect that they would prioritize elected officials as the decision-makers for energy policy. We have shown that this was not the case. An explanation for this paradox can be the Finns' low civic efficacy. The European Social Survey 2008 operationalized civic efficacy as a perception, according to which "politics is often or regularly so complicated that it is difficult to know what it is about", and Finland was ranked the third lowest among 23 European states [19]. Similarly, Rapeli [20] showed that Finns' knowledge base is not at such a level, which would enable well-argued and thorough discussion 
on political issues. However, Finns' perceptions of their own knowledge on energy issues has even strengthened; the proportion of citizens who felt that they are well acquainted with energy issues increased from $44 \%$ to $57 \%$ from 2007 to 2016. Thus far, the Finns' fact-based knowledge on energy issues has not been studied, and this is an important topic for further research. It seems likely that Finns' knowledge on energy issues concern more the substance (policy) which has been widely debated in mass media, than the process.

Citizens' willingness to be satisfied with experts representing business and public administration as opposed to elected officials - in other words, their willingness to settle for stealth democracy - is based on or at least encouraged by a misunderstanding of democratic process, as Hibbing and Theiss-Morse suggest. This may also be the case in Finland with respect to energy policy; citizens are not well-informed about the role of elected officials and experts in the political decision-making process and they overemphasize the independence and objectivity of experts and businessmen as decision-makers. Hence, teaching people to appreciate the democratic process that is designated to deal with diverse interests would be an important step toward improving their view of government [6]. However, their key argument, according to which people do not want to play a more active role in democratic procedures, does not fit without problems to Finland. On the one hand, Finns' weak civic efficacy in the field of energy policy was seen when they did not appreciate elections as an important channel for influencing energy policy, but, on the other hand, viewed themselves more and more empowered as conscious consumers through everyday consumption choices, i.e., endorsed political consumerism [23].

We concluded above that the elite structure of Finnish energy policy has moved from an exclusive pattern to the direction of a fragmented one which can be seen as positive transformation in terms of functioning of democracy. However, our findings also exposed a decreasing appreciation for classical democracy among the energy elite. While in 2007 , nine 
out of 10 energy elite members considered that those who are politically responsible to the constituency should be in charge of decision-making, the proportion was no more than twothirds in 2016. By contrast, two-fifths in 2007 and two-thirds in 2016 agreed that experts should be in charge of decision-making. Moreover, support for the idea that citizens should be able to influence decisions decreased from three-fourths to three-fifths, respectively. This attitudinal change is striking because the elite members should be well-informed about the distribution of rights and responsibilities in a democratic policy-making because of their academic education and high professional status. This findings suggest that support for elitism has increased among the energy elite; energy policy should be decided by the experts, who have no political responsibility at all, rather than the political elite. This way of thinking is consistent with what stealth democracy suggests; people do not really want to be personally more involved in politics.

However, this view can be seen as a restrictive interpretation of democracy, and it is not compatible with peoples' current desires. Support for the direct democracy in the form of a referendum has increased worldwide, even in countries where they are unusual. Finland is one of these countries where three-fourths of citizens have supported the use of national referendums in the context of important decisions since the early 2000s (64\% in 2015) [45]. For example, despite many requirements, a referendum on nuclear power has never been organized.

The Parliament of Finland enacted the Citizens' Initiative Act in 2012, the same year as the EU civic initiative came into force; if at least 50,000 citizens undersign the initiative, they can put forth a bill or a proposal to start drafting a law, and Parliament is obliged to place it on the parliamentary agenda. By February 2017, Parliament had processes 17 such initiatives out of more than 400 registered initiatives. One initiative has been accepted, and in three cases Parliament ordered the government to perform certain tasks. One of these three initiatives 
concerned the energy certificate; Parliament ordered the government to clarify the content of the Energy Certificate Act. In 2015, one-third of people reported that they have signed at least one civic initiative, and four-fifths argued that this opportunity improves democracy. Civic initiatives have especially activated young people, and raised the political agenda important questions of values, which were previously excluded from the agenda, or divided parties internally. [45]. All in all, the high popularity of referendums and civic initiatives do not support the key claim of stealth democracy, according to which, people do not really want to be personally more involved in politics.

Acknowledgements: The study was funded by the Strategic Research Council at the Academy of Finland

\section{References}

[1] J.E. Chubb, J., Interest Groups and the Bureaucracy, The Politics of Energy. Stanford University Press, Stanford, 1983.

[2] A. Prontera, Energy Policy: Concepts, Actors, Instruments and Recent Developments. World Political Sci. Rev. 5(1) (2009) 1-30.

[3] Removed

[4] A. Swift, Political Philosophy, $3^{\text {rd }}$ ed., Polity Press, Cambridge, 2014.

[5] J. Rachels, The Elements of Moral Philosophy, $5^{\text {th }}$ ed., McGrew-Hill, Boston, 2007.

[6] J. R. Hibbing, E. Theiss-Morse, Stealth Democracy. Americans' Beliefs about How Government Should Work, Cambridge University Press, Cambridge, 2005.

[7] Å. Bengtsson, M. Mattila, Direct Democracy and its Critics: Support for Direct Democracy and 'Stealth Democracy' in Finland. West Eur. Politics 32(5) (2009) 1031-1048. 
[8] Å. Bengtsson, Citizens' perceptions of political processes: A Critical Evaluation of Consistency and Survey Items. Revista Internacional de Sociologia 70(2) (2012) 45-60.

[9] Removed

[10] M. Rask, Expanding Expertise in Science and Technology Decision Making. Futura 27(3) (2008) 76-81.

[11] D. Rucht, The Impact of Anti-Nuclear Power Movements in International Comparison, in: M. Bauer, M. (Ed.), Resistance to New Technology. Nuclear Power, Information technology and Biotechnology, Cambridge University Press, Cambridge, 1997, pp, 277-292.

[12] Science Barometer, Tieteen tiedotus ry., Helsinki, 2016.

[13] T. Litmanen, M. Kojo, Not Excluding Power: the Dynamics and Stability of Nuclear Power Policy Arrangements in Finland. J. of Integ. Environ. Sci.8(3) (2011) 171-194.

[14] M. Kuisma, T. Keskisarja, Erehtymättömät. Tarina suuresta pankkisodasta ja liikepankeista Suomen kohtaloissa. WSOY, Helsinki, 2012.

[15] M. Pohjola, Taantuma ei ollut ennätyksellisen syvä. Helsingin Sanomat, 1st December, 2010.

[16] A. Kantola, J. Vesa, Skandaalit ja julkinen elämä Suomessa, in: A. Kantola (Ed.), Hetken hallitsijat. Gaudeamus, Helsinki, 2011, pp. 42-64.

[17] P. Norris, Democratic Deficit. Critical Citizens Revisited. Cambridge University Press, New York, 2011.

[18] Eurostat, Quality of life in Europe - facts and views - governance.

$\underline{\text { http://ec.europa.eu/eurostat/statistics-explained/index.php?title=Quality_of_life_in_Europe _- }}$ 
_facts_and_views_-_governance\&oldid=270643\#Trust_in_institutions_and_trust_in_others,

2015 (accessed 6.1.2017).

[19] E. Kestilä-Kekkonen, Puoluedemokratian haasteet, in: T. Forsberg, T. Raunio, (Eds.), Politiikan muutos, Vastapaino, Tampere, 2014, pp. 41-76.

[20] L. Rapeli, Tietääkö kansa? Kansalaisten politiikkatietämys teoreettisessa ja empiirisessä tarkastelussa. Annales Universitatis Turkuensis, Ser. C, Tom 296, University of Turku, Turku 2010.

[21] Energy Attitudes 2007, Research report 25.4.2008. Finnish Energy Industries, Helsinki. /http://www.sci.fi-yhdys.eas._07/eas-tied 07.htms. (accessed 27.8.2008).

[22] D. Stolle, M. Micheletti, Political Consumerism. Global Responsibility in Action, Cambridge University Press, New York, 2013.

[23] Removed

[24] J. A. Schumpeter, Capitalism, Socialism and Democracy. Eight impression, Allen \& Unwin. London, 1959.

[25] H. Paloheimo, S. Borg, Eduskuntavaalit yleisödemokratian aikakaudella, in: S. Borg, H. Paloheimo (Eds.), Vaalit yleisödemokratiassa. Eduskuntavaalitutkimus 2007, Tampere University Press, Tampere, 2009, pp. 357-276.

[26] F. Fischer, Technocracy and the Politics of Expertise. Sage, London, 1990.

[27] S. Kuitunen, K. Lähteenmäki-Smith, Eliittien pelikenttä? Teknologiapolitiikan malli ja periaatteet Suomessa, Polit. 48(2) (2006) 99-114.

[28] J. Peterson, M. Sharp, Technology Policy in the European Union. MacMillan, New York, 2001. 
[29] T. Lemola, Tiede- ja teknologiapolitiikan muutostarpeet, in: T. Lemola, P. Honkanen, (Eds.), Innovaatiopolitiikka. Kenen hyväksi, keiden ehdoilla? Gaudeamus, Helsinki, 2004, pp. 290-303.

[30] E. Etzioni-Halevy, The Elite Connection. Problems and Potential of Western Democracy, Polity Press, Cambridge, 1993.

[31] C. W. Mills, The Power Elite, Oxford University Press, New York, 1956.

[32] Removed

[33] OECD, Society at a Glance: The Crisis and its Aftermath: OECD Social Indicators, www.oecd.or/publishing, (accessed 27.3.2014).

[34] H. Wass, S. Borg, Yhdenvertaisuus äänestyskopissa vuoden 2015 eduskuntavaaleissa, in: K. Grönlund, H. Wass (Eds.), Poliittisen osallistumisen eriytyminen. Eduskuntavaalitutkimus 2015, Selvityksiä ja ohjeita 28, oikeusministeriö, Helsinki, 2016, pp. 177-199.

[35] Statistics Finland 2008. Statistical Year Book of Finland. Statistics Finland, Helsinki, 2008

[36] Statistics Finland 2016. Statistical Year Book of Finland. Statistics Finland, Helsinki, 2016.

[37] U. Hoffman-Lange, Ursula, Surveying National Elites in the Federal Republic of Germany, in: G. Moyser, M. Wagstaffe (Eds.), Research Methods for Elite Studies. London, Allen and Unwin, 1987, pp. 27-47.

[38] R. Hertz, J.B. Imber (Eds), Studying Elites Using Qualitative Methods. Sage, London, 1995.

[39] Removed 
[40] G. King, R.O. Keohane, S. Verba, Designing Social Inquiry, Princeton University Press, Princeton, 1994.

[41] L. Rapeli, S. Borg, Kiinnostavaa mutta monimutkaista: tiedot, osallistuminen ja suhtautuminen vaikuttamiseen, in: K. Grönlund, H. Wass (Eds.), Poliittisen osallistumisen eriytyminen. Eduskuntavaalitutkimus 2015, Selvityksiä ja ohjeita 28, oikeusministeriö, Helsinki, 2016, pp. 358-378.

[42] S. J. Pharr, R.D. Putnam (Eds.), Disaffrected Democracies, Princeton University Press, Princeton, 2000.

[43] J. A. J. Evans, Voters and Voting. An Introduction, Sage, London 2004.

[44] M. X. Delli Carpini, S. Keeter, What Americans Know about Politics and Why it Matters, Yale University Press, New Haven, 1996,

[45] H. Serup Christensen, M. Karjalainen, M. Setälä, Kansalaisaloite poliittisen yhdenvertaisuuden näkökulmasta, in: K. Grönlund, H. Wass (Eds.), Poliittisen osallistumisen eriytyminen. Eduskuntavaalitutkimus 2015, Selvityksiä ja ohjeita 28, oikeusministeriö, Helsinki, 2016, pp. 435-456. 
Table 1: The views of the energy elite and the citizenry on the statements dealing with the substance of the energy policy in 2016 (agree fully or somewhat \%)
Statement
Elite
Citizenry
Difference E-C

Climate change is serious, but is has received far too

little attention in our country's political decision-making. 44

61

Finland's dependence on the energy imports from

Russia should be reduced.

A centralized energy system based on large-scale energy production units is better than the decentralized system based on small-scale energy production units.

The EU should direct the member states' energy policy to a greater extent than they do today.

There is sufficient competition between electricity

suppliers.

Finland should strive for the national energy

self-sufficiency by 2030 .

Public subsidies for the energy policy should be increased

that new technology can be put into operation more quickly than it is today.

Energy markets should be allowed to operate on the market terms.

Use of petroleum and diesel as traffic fuels should be discontinued by 2030 .

Finland should move entirely to the use of renewable energy sources by 2030 . 
Table 2: The proportion of the energy elite and the citizenry who preferred to increase (substantially or somewhat) the use of various energy sources in the future (\%)

Energy source

2007

2016

Elite

Citizenry

Difference Elite

Citizenry

Difference

E-C

E-C

Wind power 96

87

$+9$

74

77

$-3$

Biogas 96

$69+26$

88

74

$+14$

Wood fuels 96

64

$+32$

77

52

$+25$

Nuclear

power

43

$+41$

43

22

$+29$

Solar energy 76

91

$-15$

92

91

$+1$

Hydroelectric

power 66

Peat 33

65

$+1$

54

60

$-6$

Natural gas 25

39

$-6$

22

$-10$

Coal

4

43

$-18$

34

$-4$

Oil

0

4

0

2

$-1$

$-3$

2

$-1$

\section{Coherence}

index

70.5

53.8

62.3

53.7

Attitudinal

distance

(standard

deviation)

15.2

8.7

$\mathrm{N}=$

93 
Table 3: The proportion of the energy elite and the citizenry who perceived very or somewhat important the principles concerning the process of energy policy-making in 2007 and 2016 (\%)

Principle

2007

Elite

Decision should be

announced as openly as

possible.

100

Experts should be in charge

of the drafting of decisions. 100

Societal effects of decisions

should be taken widely

into account.

100

Decisions should take

account of various interest

groups.

96

67

$+29$

68

69

$-1$

Environmental effects of

decisions should be taken

widely into account.

92

95

$-3$

99

92

$+7$

Those politically responsible

to the constituency should

be in charge of decision-

making.

92

54

$+38$

68

56

$+12$

The drafting process of

decisions should be open.

88

90

$-2$

91

89

$+2$

Citizens should be able to

influence decisions.

75

$+1$

61

75

$-14$

Experts should be in charge

of decision-making.

38

91

$-52$

68

89

Representatives of firms

should take part in

decision-making.

67

62

$+5$

68

66

$+2$

Business organizations 
should play a central role

in decision-making. $\quad 67$

41

$+26$

48

48

0

Decisions should be made by

consensus based on

negotiations.

33

65

$-32$

32

64

$-32$

Environmental organizations

should play a central role in

decision-making.

30

54

$-24$

28

53

$-25$

Energy policy should be

determined free of

governmental direction

12

29

$-17$

21

32

$-11$

Coherence index

66.4

53.4

55.4

52.6

Attitudinal distance

(standard deviation)

17.4

10.1

$\mathrm{N}=$

24

1189

93

1349 
Table 4: Proportion of supporters of stealth democracy among various socio-economic citizen groups in 2007 and 2016 (\%)

$\underline{\text { Sex }}$

Men

78

77

Women

78

80

$p>.05$

$p>.05$

Age group

18-29

72

73

30-44

74

75

45-59

79

76

60-75

83

83

$p<.05$

$p<.01$

Basic education

Primary school

78

79

Elementary school

80

80

High school

77

78

$p>.05$

$p>.05$

$\underline{\text { Vocational education }}$

No vocational education

74

75

Vocational course

82

82

Vocational school

79

78

Polytechnic

78

81

University

76

78

$p>.05$

$p>.05$

\section{Occupational position}

Leading position

Upper functionary

Lower functionary

Blue-collar worker

Entrepreneur

Farmer
76

72

77

76

84

76
76

72

85

77

82

90 
Homemaker

Unemployed

89 67

Other

p>.05

p>.05

$\underline{\text { Political affiliation }}$

Centre Party

81 87

Conservatives

82 84

Social Democrats

82

83

Left Alliance

88

83

Swedish People's Party

73 87

Greens

84

74

Christian Democrats

76

90

Finns' Party

74

73

Would not vote at all

71 66

Can't say 72

82

Do not want to disclose

70 75

$\mathrm{p}>.05$ $p<.05$ 